\title{
Current poverty and income distribution in the context of South African history
}

SERVAAS VAN DER BERG

Stellenbosch Economic Working Papers: 22/10

October 2010

KEYWORDS: SOUTH AFRICA, POVERTY, INCOME DISTRIBUTION, LABOUR MARKET

JEL: O15, D31, D63, J31, N37

SERVAAS VAN DER BERG

DEPARTMENT OF ECONOMICS

UNIVERSITY OF STELLENBOSCH

PRIVATE BAG X1, 7602

MATIELAND, SOUTH AFRICA

E-MAIL: SVDB@SUN.AC.ZA 


\title{
Current poverty and income distribution in the context of South African history ${ }^{1}$
}

\author{
SERVAAS VAN DER BERG ${ }^{2}$
}

ABSTRACT

This paper describes and analyses current poverty and income distribution in South Africa, with a central concern the relationship between poverty, inequality and growth. The paper also investigates patterns of and trends in poverty and income distribution, a literature with a long and distinguished history. Drawing from recent literature in this regard, the paper shows that the labour market rather than access to wealth or to political and fiscal power - currently sets the limits to redistribution. Wage inequality, deeply rooted in South Africa's history, plays a central role in overall income distribution, and patterns of human capital development are fundamental to the future growth path and therefore to poverty and income distribution. The paper therefore concludes that reducing inequality substantially is currently unlikely without a massive increase in the human capital of those presently poor, but that prospects in this regard are inauspicious.

Keywords: South Africa, poverty, income distribution, labour market JEL codes: 015, D31, D63, J31, N37

\footnotetext{
${ }^{1}$ The author wishes to thank Derek Yu for direct assistance with some data work for this paper, and a whole team of people within the NRF Research Chair in the Economics of Social Policy at the University of Stellenbosch for their support in the ongoing work that underlies this paper. Where data sources for tables and figures are not mentioned, the source is own calculations within this Social Policy Research Group at the University of Stellenbosch. ${ }^{2}$ The author is NRF Research Chair in the Economics of Social Policy, attached to the Department of Economics
at the University of Stellenbosch
} 


\title{
Current poverty and income distribution in the context of South African history
}

\author{
Servaas van der Berg
}

"(T)here is not one distribution of income but many: income is distributed across racial groups, income classes, present and future generations, and so on. Moreover, a given distribution is not a one-dimensional magnitude: it has as many dimensions or components as there are relevant 'classes'." (Norman Bromberger, 1982, p.166)

\section{Introduction and background}

In South Africa with its high levels of racial inequality, inequality in income distribution is especially large and persistent. For an upper-middle income country (in terms of GDP per capita and economic structure), South African social indicators (e.g. life expectancy, infant mortality or quality of education) are closer to those of lower-middle income or even low income countries. This reflects the unequal distribution of resources and opportunities. A small group of highincome earners sharply increases average incomes, but has little impact on average social indicators, which are low because of this very same inequality. Even in 1995, before the full advent of AIDS, South African life expectancy at birth was only 63 - ten years less than that of Panama, a country of comparable income, and four years less than that of the Philippines, a country with one-third of South Africa's per capita income (World Bank 1997).

It is common to ascribe South African inequality and even poverty to racial discrimination and in particular to apartheid. This of course offers only a part of the explanation. In a poor pre-colonial society, colonial settlement and then the mineral discoveries laid the basis for a highly dualistic economy that was from the outset highly inegalitarian. Racial discrimination under first British colonial rule and then apartheid distributed the spoils of economic growth along racial lines, which laid the foundation for patterns of further development and privilege in a society stratified by race. The post-apartheid government implemented policies that explicitly tried to overturn these patterns of privilege.

Against this background, this paper describes and analyses current poverty and income distribution in South Africa. A central concern is the relationship between poverty, inequality and growth, dealt with in the next section. Subsequent sections investigate patterns of and trends in income distribution and poverty, a literature that has a long and distinguished history. In this brief summary of the most recent part of that literature, the paper will show that the labour market - rather than access to wealth or to political and fiscal power - currently sets the limits to redistribution. Wage inequality, deeply rooted in South Africa's history, plays a central role, and patterns of human capital development are fundamental to the future growth path and thereby to poverty and inequality. Therefore the conclusion is that substantially reducing inequality is now unlikely without a massive increase in the human capital of those presently poor; unfortunately, prospects in this regard are inauspicious. 


\section{Income inequality, headcount poverty and growth}

For a given average income level of a country, high inequality usually can be associated with high levels of headcount poverty. The terms poverty and inequality are often intertwined, in a manner that suggests that these two factors are closely related. This is not necessarily true in a historical sense, as the association between inequality and poverty breaks down when average incomes are growing as a result of economic growth, when such growth is large and sustained over a substantial period. Even though rising inequality may prevent poverty from declining rapidly, the effect of rapid and long term economic growth is likely to dominate the inequality effect. Most developed countries today probably have greater income inequality yet far less poverty than half a millennium ago, and the same probably applies to developing countries in the past 200 years. Maddison's path breaking quantitative estimates show per capita income of the African continent to have been about $\$ 420$ in 1820 , almost the same value as in A.D.1, when it was still close to the world average (Maddison 2007). Yet by 2000, average incomes of black South Africans were perhaps three times as large (depending on the exchange rate used to convert). Thus poverty had declined since early colonial times, though one may lament the slow rate of this decline. In contrast, there can be little doubt that there is now far greater inequality than before colonial settlement.

But even in the short run, the assumed narrow association between headcount poverty and inequality does not always hold. Higher inequality could increase poverty, or reduce it, depending where the poverty line is deemed to lie relative to the modal incomes in the income distribution. This can be illustrated as follows: Figure 1 shows kernel density curves of income distribution by race from IES2005. White incomes far exceed those of blacks and consequently lie to the right, with coloureds and Indians taking intermediate positions. There is limited overlap between white and black incomes. If a poverty line is selected, as illustrated by the vertical line on the left, to run approximately through the mode of the black income distribution, on this log scale, this would leave roughly half the black population in poverty. In such a situation, greater income inequality amongst blacks and the consequent widening of the density curve would have little effect on the black poverty headcount, i.e. the proportion of the population deemed to be poor, though it would affect poverty measures that are more sensitive to low incomes, such as the $\mathrm{P}_{1}$ measure (the poverty gap ratio) or the $\mathrm{P}_{2}$ measure (the poverty severity ratio or squared poverty gap ratio). ${ }^{3}$ In this paper, as in much of the literature, reference to poverty is usually to headcount poverty as measured in money-metric terms, relative to some chosen poverty line. However, a more nuanced view of poverty, that also gives greater attention to Foster-GreerThorbecke's $\mathrm{P}_{1}$ and $\mathrm{P}_{2}$ measures, is to be encouraged. Amongst other things, poverty measures

\footnotetext{
${ }^{3} \mathrm{P}_{\mathrm{o}}, \mathrm{P}_{1}$ and $\mathrm{P}_{2}$ are three poverty measures used within the Foster-Greer-Thorbecke (FGT) class of measures. $\mathrm{P}_{0}$, the poverty headcount ratio, is the most commonly used measure, but insensitive to the situation of the poor. $\mathrm{P}_{1}$, the poverty gap ratio, considers how far the poor are removed from the poverty line, while $\mathrm{P}_{2}$, the poverty severity ratio or squared poverty gap ratio, also considers distribution amongst the poor by weighting the poorest most heavily. Thus $\mathrm{P}_{1}$ and especially $\mathrm{P}_{2}$ are measures that are more sensitive to the position of the poorest.
} 
that are more sensitive to the position of the poorest are to be preferred because they are less sensitive to the choice of poverty line. ${ }^{4}$

A worsening income distribution within other population groups, reflected in a widening of their density curves, would place more people below the poverty line. In such cases, the poverty headcount ratio and inequality would move in the same direction.

A similar situation applies for the second vertical line, which can be regarded as either a poverty line set very high, or an affluence threshold. A worsening income distribution amongst blacks would move some people above the affluence threshold (or out of poverty if the poverty line were set at such an inappropriately high level). That is precisely how the recent rise of the black middle class can be perceived: growing inequality amongst blacks is associated with growing numbers of people moving into higher income groups or into affluence. If a poverty line were set at such a level, worsening income distribution would have meant less rather than more headcount poverty.

\footnotetext{
${ }^{4}$ Some contentious issues regarding the choice of both poverty line and poverty measure $\left(\mathrm{P}_{0}, \mathrm{P}_{1}\right.$ or $\left.\mathrm{P}_{2}\right)$ can be avoided if first order stochastic poverty dominance can be demonstrated, i.e. if the ordering of the poverty headcount remains unchanged irrespective of the poverty lines, in which case the same ordering would apply for any of the three FGT measures as well at any conceivable poverty line. Such dominance can be shown using cumulative density functions. Though much of the SA poverty measurement literature now takes cognisance of this, summaries of this literature in this paper largely relate to the poverty headcount at a poverty line that varies across different studies.
} 
Figure 1:

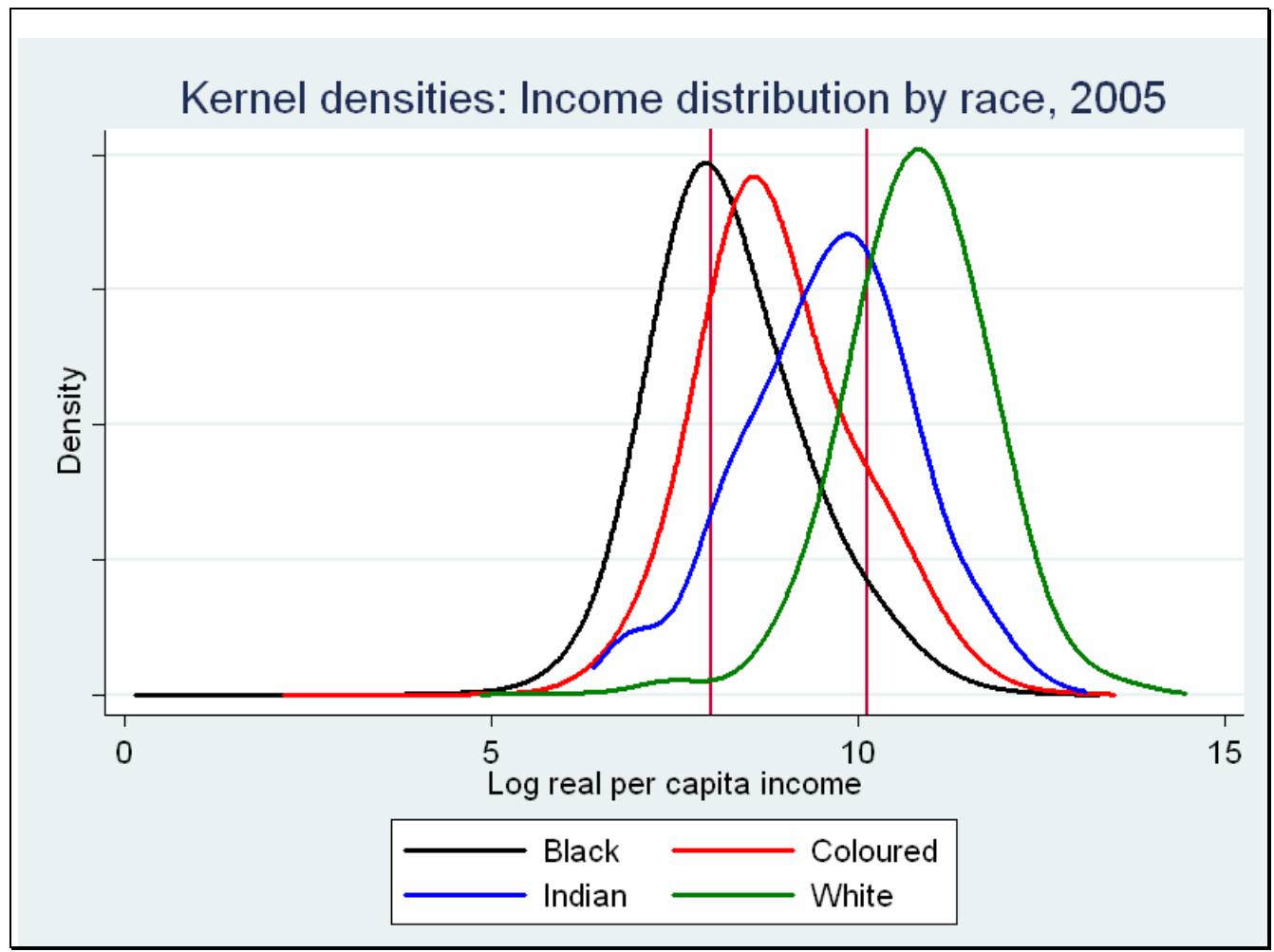

Thus, as a rule of thumb and for the reasons discussed, if the income poverty line lies to the left of modal incomes, then income inequality will usually worsen headcount poverty, while a poverty line above the mode means that increased inequality will push more people above the poverty line.

To this relationship between inequality and poverty needs to be added the relationship with growth. Economic growth shifts distributions to the right, thus poverty would decline unless income distribution worsens enough to counter this growth. Economic growth with unchanged income distribution would benefit all and reduce poverty. It is even possible - and probably also occurred for a period after the turn of the $21^{\text {st }}$ century - that income inequality can worsen while poverty substantially declines as a result of economic growth. The more growth there is, the less likely that growing inequality can prevent the beneficial effects of growth from reducing poverty. On the other hand, sharp increases in inequality can overturn the effect of even large growth episodes. Thus growth and trends in inequality jointly determine trends in poverty.

South Africa's household income per person in 2010 in current Rand values was about R31 600, versus approximately R9 000 in 1910 measured in the same purchasing power. ${ }^{5}$ Over that century, then, per capita income had grown by about one and a quarter percent per annum, but

\footnotetext{
5 Author's own estimates based on published national accounts data and population estimates, and with some provision for changes in definitions used in the national accounts.
} 
due to the power of compound interest, aggregate growth was $250 \%$. How did that affect measured poverty? That is no easy question answer, but a small simulation exercise will illustrate what the effect of this growth may have been under alternative scenarios regarding income distribution.

Assume a log-normal distribution of income, which is indeed a close enough approximation for most income distributions and an assumption widely used in the literature. ${ }^{6}$ Assume also that the Gini coefficient for 2010 was 0.72 (approximately the value obtained in 2007) ${ }^{7}$ (a standard deviation of log-income set at about 1.522 generates such a Gini). The Gini coefficient for 1910 must clearly have been lower. We allow for four possibilities, ranging from 0.30 to 0.60 . To investigate the impact of growth and distribution on poverty requires setting a fixed poverty line, by the maxim "when you want to measure change, don't change the measure." Similar to poverty lines in the European Union, the poverty lines chosen for this exercise were about $60 \%$ of median per capita income, viz. R6 000 per capita per year based on the 2010 distribution, and R2 600 for 1910 (for the case where the Gini has been set at 0.60).

The results are presented below. For 1910, assumed Ginis were set to range from 0.30 to 0.60 , while the income distribution for 2010 shows the much greater inequality South Africa now has. Table 1 illustrates that even a century of moderate economic growth may not necessarily reduce poverty, if inequality rises greatly during that period. This is particularly true for poverty measures most sensitive to the position of the poorest, e.g. where the poverty line is set at a lower level, or where $\mathrm{P}_{1}$ and $\mathrm{P}_{2}$ are used rather than the headcount ratio, $\mathrm{P}_{0}$. For more moderate increases in inequality, the effect of growth is likely to dominate and poverty reduction is likely to accompany growth.

Table 1: Simulation of the impact of a century of growth and distribution on South African poverty

\begin{tabular}{|c|c|c|c|c|c|c|c|c|}
\hline \multirow[b]{2}{*}{ Year } & \multirow{2}{*}{$\begin{array}{l}\text { Assumed per } \\
\text { capita income } \\
\text { (2010 Rand } \\
\text { values) }\end{array}$} & \multirow{2}{*}{$\begin{array}{c}\text { Assumed } \\
\text { Gini } \\
\text { coefficient }\end{array}$} & \multicolumn{3}{|c|}{ Poverty line R6 000} & \multicolumn{3}{|c|}{ Poverty line R3 600} \\
\hline & & & $\mathbf{P}_{0}$ & $\mathbf{P}_{1}$ & $\mathbf{P}_{2}$ & $\mathbf{P}_{0}$ & $\mathbf{P}_{1}$ & $\mathbf{P}_{2}$ \\
\hline 2010 & R31 600 & 0.72 & 0.3699 & 0.2022 & 0.1378 & 0.1888 & 0.0905 & 0.0567 \\
\hline \multirow{4}{*}{1910} & \multirow{4}{*}{ R9000 } & 0.30 & 0.3181 & 0.0865 & 0.0338 & 0.0222 & 0.0038 & 0.0011 \\
\hline & & 0.40 & 0.4339 & 0.1622 & 0.0817 & 0.0969 & 0.0256 & 0.0101 \\
\hline & & $\mathbf{0 . 5 0}$ & 0.5199 & 0.2451 & 0.1476 & 0.2051 & 0.0748 & 0.0379 \\
\hline & & 0.60 & 0.6018 & 0.3417 & 0.2354 & 0.3320 & 0.1556 & 0.0948 \\
\hline
\end{tabular}

Note: Shaded cases are those where measured poverty in 1910 was lower than in 2010

\footnotetext{
${ }^{6}$ In a heated recent debate about trends in world poverty, this assumption of his was not really challenged, though many other assumptions of Sala-i-Martin's estimates were (see Sala-i-Martin 2002a, 2002b; Bourguignon \& Morrisson 2002; Quah 2002).

${ }^{7}$ Many studies that record lower Gini coefficients use datasets that do not accurately capture some higher incomes. Some authors (e.g. the World Bank in its World Development Reports) report inequality in household income, but the method employed throughout for these figures was to compare all individual incomes, thus weights were derived by multiplying household weights by the household size, as Deaton (1997) prescribes for such situations.
} 
So what was the case in South Africa over the past century? No data exists to give a definitive answer $^{8}$, but the great extent of racial inequality known to exist a century ago (see e.g. Spandau 1971) makes it likely that overall income distribution was already very unequal in 1910 (simply assuming equal within-group incomes and applying that to Spandau's racial income share estimates for 1917 already gives a Gini of 0.53), though it undoubtedly grew further over the century. Thus one may suspect that the 1910 Gini coefficient, if measured in the same manner and with similar information as currently, may have been somewhere in the range 0.50 to 0.60 , probably closer to the latter value. If this was indeed true, the poverty headcount must have declined considerably since Union using the higher poverty line: The headcount ratio has fallen by as much as 23 percentage points. But if a lower poverty line is considered, or when using poverty measures more sensitive to the position of the poorest, poverty may even have worsened if poverty inequality had risen from lower levels than assumed. South Africa's history of rising inequality was clearly bad for poverty reduction, and what growth there was may not have benefited the poorest much.

Have trends improved in the more recent past? The next section investigates this issue.

\section{Income distribution and poverty: Understanding post-transition trends}

\section{Data and measurement issues in South Africa}

Although recent years saw an explosion of data sources for estimating poverty and distribution trends, estimates remain greatly uncertain. Reasons include measurement difficulties (including data validity and comparability issues, differences in sampling frames, sample attrition and nonresponse, changes in survey instruments and inconsistencies in how field workers interpret and apply definitions); that different surveys and censuses classify income and that different researchers deal with missing values of income or recorded zero incomes in widely varying ways; and that respondents in many surveys are not sufficiently prompted to recall all possible income sources, thereby leading to under-reporting of income from various sources by varying degrees.

To illustrate: The proportion of national accounts current income directly captured in the census (after imputations to deal with missing data) was only $42 \%$ in 1996, but rose to $65 \%$ in the 2001 census and to $91 \%$ in the 2007 Community Survey (Yu 2009, 46). This renders comparisons across these data sources suspect. Similar issues arise with the Income and Expenditure Surveys: While food expenditure values in earlier surveys was obtained though respondent recall, IES2005 implemented a weekly diary for four weeks, giving rise to respondent fatigue, especially amongst higher income respondents. Consequently, recorded food expenditure fell sharply from $18.3 \%$ to $9.6 \%$ of all expenditure, caused by an unlikely combination of a $14 \%$

\footnotetext{
${ }^{8}$ Whiteford and McGrath (1994: 15) point out that "Prior to 1979 no satisfactory attempts had been made at calculating how personal income was distributed among earners or households." The first attempts to estimate such distribution were for 1970 and subsequent years.
} 
recorded decline in real food expenditure and a $64 \%$ increase in recorded aggregate consumption expenditure over a five year period ( $\mathrm{Yu}$ 2008, 16, Table 10). Data comparisons are thus hazardous. This applies especially for income distribution estimates, as these are also sensitive to the accuracy of measurement of high incomes, including profits, dividends and other property income. Thus Charles Simkins $(2000,13)$ rightly reminds us that "The art of measurement lies in painstaking reconciliation of information (which is sometimes years in arrears), supplemented by the use of judgement. Up to now, the margin of error has been much wider than one would like, making estimates controversial."

\section{Trends in inter-racial income distribution}

In 1971 Spandau $(1971,195)$ wrote that "The main distinguishable feature of the distribution of income by race is its relative constancy during the 35 year period 1924/25 to 1960." Despite a rising black population share, this stability in racial income shares continued until about 1970. However, between 1970 and the end of the century the black share of income increased sharply from $22 \%$ to $38 \%$ (Table 2 presents one set of estimates), bringing to an end a long period of widening racial income inequality.

Table 2: Estimates of total and per capita income, 1970-2000 (in 2000 Rand values)

\begin{tabular}{|c|c|c|c|c|c|c|c|}
\hline & 1970 & 1975 & 1980 & 1985 & 1990 & 1995 & 2000 \\
\hline \multicolumn{8}{|l|}{ All income } \\
\hline Blacks & $\mathrm{R} 50454 \mathrm{~m}$ & $\mathrm{R} 82683 \mathrm{~m}$ & $\mathrm{R} 108131 \mathrm{~m}$ & $\mathrm{R} 132553 \mathrm{~m}$ & $\mathrm{R} 170630 \mathrm{~m}$ & $\mathrm{R} 212294 \mathrm{~m}$ & $\mathrm{R} 252071 \mathrm{~m}$ \\
\hline Coloureds & $\mathrm{R} 17513 \mathrm{~m}$ & $\mathrm{R} 20999 \mathrm{~m}$ & $\mathrm{R} 23854 \mathrm{~m}$ & $\mathrm{R} 29436 \mathrm{~m}$ & $\mathrm{R} 36784 \mathrm{~m}$ & $\mathrm{R} 44417 \mathrm{~m}$ & $\mathrm{R} 53111 \mathrm{~m}$ \\
\hline Indians & R6 298m & $\mathrm{R} 8361 \mathrm{~m}$ & $\mathrm{R} 10892 \mathrm{~m}$ & $\mathrm{R} 13635 \mathrm{~m}$ & $\mathrm{R} 17181 \mathrm{~m}$ & $\mathrm{R} 21480 \mathrm{~m}$ & $\mathrm{R} 26396 \mathrm{~m}$ \\
\hline Whites & $\mathrm{R} 151963 \mathrm{~m}$ & R189 279m & $\mathrm{R} 211504 \mathrm{~m}$ & $\mathrm{R} 235605 \mathrm{~m}$ & $\mathrm{R} 260835 \mathrm{~m}$ & $\mathrm{R} 277411 \mathrm{~m}$ & $\mathrm{R} 326307 \mathrm{~m}$ \\
\hline Total & $\mathrm{R} 226228 \mathrm{~m}$ & $\mathrm{R} 301321 \mathrm{~m}$ & $\mathrm{R} 354381 \mathrm{~m}$ & $\mathrm{R} 411230 \mathrm{~m}$ & $\mathrm{R} 485429 \mathrm{~m}$ & $\mathrm{R} 555601 \mathrm{~m}$ & $\mathrm{R} 657884 \mathrm{~m}$ \\
\hline \multicolumn{8}{|c|}{ Per capita income } \\
\hline Blacks & R 3134 & R 4479 & R 5107 & R 5423 & R 6008 & R 6704 & R 7283 \\
\hline Coloureds & R 8184 & R 8630 & R 8822 & R 9855 & R 11404 & R 12722 & R 14126 \\
\hline Indians & R 9595 & R 11244 & R 13296 & R 15113 & R 17637 & R 20592 & R 23938 \\
\hline Whites & R 39217 & R 44242 & R 46670 & R 48370 & R 51951 & R 53840 & R 62360 \\
\hline Total & R 9936 & R 11626 & R 12125 & R 12385 & R 12903 & R 13436 & $\mathrm{R} 14716$ \\
\hline
\end{tabular}

Source: Van der Berg \& Louw 2004, using estimates derived from a variety of sources

The income of any group can be considered to consist of wages (the product of the average wage and the number employed) plus income from assets (i.e. income from the other factors of production, capital, land and entrepreneurship) plus income from social grants (transfers). The most important income components are wage levels, employment (relative to the size of the population) and social grants. The relationship can be written as:

$$
\mathrm{Y}=\mathrm{W} x \mathrm{E}+\mathrm{Y}_{\mathrm{a}}+\mathrm{Y}_{\mathrm{g}}
$$

(Equation 1)

and thus

$$
\mathrm{Y} / \mathrm{P}=\mathrm{W} \times \mathrm{E} / \mathrm{P}+\mathrm{Y}_{\mathrm{a}} / \mathrm{P}+\mathrm{Y}_{\mathrm{g}} / \mathrm{P}
$$


where $\mathrm{Y}$ is the income of a group, $\mathrm{P}$ is its population size, $\mathrm{W}$ the mean wage of that group, $\mathrm{E}$ the number employed, $\mathrm{Y}_{\mathrm{a}}$ is income from assets and $\mathrm{Y}_{\mathrm{g}}$ income from social grants.

This can be interpreted in the following way: If the average wage $\mathrm{W}$ rises or the number of employed compared to the population $(\mathrm{E} / \mathrm{P})$ rises, then per capita income will increase, ceteris paribus. Asset income $\left(\mathrm{Y}_{\mathrm{a}}\right)$ for a particular group is less likely to change markedly in any short time span, as asset accumulation is a slow process. Grant incomes $\left(\mathrm{Y}_{\mathrm{g}}\right)$ can change more rapidly; in South Africa they have increased sharply in recent years.

This conceptual framework facilitates an investigation of inter-group inequality trends in the post-1970 period, and most usefully it allows an analysis of trends in the per capita incomes of blacks, the numerically dominant group. The long stagnation of black wages on the mines and the slow progress in other sectors came to an abrupt end in the early 1970s, with a combination of gold price rises, union action and international pressure giving rise to rapid wage increases for this group (Van der Berg 1989a, 1989b). These wage rises moderated during the 1990s and slowed to only modest wage movements since, largely commensurate with skill and productivity improvements. But rising unemployment from the 1970s restricted black per capita income growth. Even though employment growth accelerated a little in the 1990s, this was not enough to keep up with the rapid rise in labour force participation. By September 2009, narrow unemployment was 28.8 percent for blacks against 4.6 percent for whites; coloureds (21.6 percent) and Indians (12.7 percent) occupied intermediate positions.

There were also some shifts in ownership of assets which generate income (dividends and land rent). But direct asset ownership by blacks remains relatively small, thus asset income does not contribute much to aggregate black incomes.

Social grants for the black population also expanded through the gradual move towards grant equalisation from the mid-1970s - grant values were equalised before the political transition. A further massive expansion of grants occurred after the turn of the century. Grants are an important income source for those who are poorly linked to the labour market. In this manner, incomes at the bottom of the distribution could rise despite their benefiting little from market trends. Grant spending increased by R600 per capita over the whole population in the last eight years, with the effect being larger and concentrated at the bottom of the distribution.

Given all these factors, income inequality between white and black was reduced, in part because some black people benefited from new economic opportunities in the post-transition period. This affected income distribution within the black population and gave rise to a growing black middle class.

There have been no reliable estimates of the distribution of wealth (assets) since the pioneering work of Michael McGrath (1983, 1990a, 1990b; McGrath \& Whiteford 1994; Whiteford \& McGrath 1994). As in all societies, however, this distribution can be expected to be more unequal than the distribution of income. The propensity to save increases with income, implying higher rates of accumulation amongst the more affluent. In addition, wealth, once accumulated, is transmitted across generations. In South Africa, most black people were prevented from accumulating the most common assets, residential properties, during apartheid. Also, given other 
immediate priorities, few black people have yet started investing on scale: For instance, only $0.46 \%$ had bought shares on the Johannesburg Stock Exchange in 2009, compared to 4.79\% of whites (own calculations from AMPS data).

Though the rise of black middle class has been linked with affirmative action and black economic empowerment policies, it can also be seen as a natural tendency in a modern economy in which the black population numerically dominates - the political transition may just have accelerated a process already well under way by 1994 (Kane-Berman 1991). It is not possible on available information to separate the relative effect on distributional outcomes of natural socioeconomic trends from deliberate government policies to increase black representation in higher skilled occupations and industries. Whatever the case, the trend towards normalisation inexorably continued after the transition: The black share of the richest quintile of the population rose substantially, from $22 \%$ in 1993 to $42 \%$ in 2008 (though this remains far below their population share). According to AMPS data, the number of black people in households earning more than R40 000 per capita in 2000 Rand terms increased from 0.4 million in 1994 to 1.9 million in 2008, an increase of 1.5 million, while the total population in this group increased by only 2.0 million, from 3.2 to 5.2 million. Thus blacks became the largest part of the increment in the middle class.

But not all many black members of the middle class have yet consolidated their economic position. First generation members of the middle class are often economically relatively insecure because they may have few assets and durable consumer goods. This accounts for black middle class consumption patterns that differ significantly from those of more established middle classes. Thus, for instance, rich black households are less likely to own dishwashers or vehicles than their counterparts in other race groups, while they are more active purchasers of such goods, often spending their discretionary income on accumulating assets and consumer durables.

\section{Aggregate income distribution and poverty trends}

Recent studies of income distribution have generally analysed data from the 1995, 2000 and 2005/6 IES household surveys (together with the linked 1995 October Household Survey and September 2000 LFS) or income data from the censuses conducted in 1996 and 2001 and the Community Survey of 2007. This means that one can consider two roughly similar time periods post transition. There is some coherence, but also some disagreement, in the results found for these periods. This is partly because measurement errors in surveys are exacerbated when only two data points, some years apart and each with its own errors and idiosyncrasies, are compared.

Most analyses find for the period from the transition to 2000 a moderate to strong rise in overall inequality (Statistics South Africa 2002; Hoogeveen and Özler 2006; Van der Berg \& Louw 2004; Simkins 2004; Ardington et al. 2005; Leibbrandt et al. 2006; Yu 2008, 2009, 2010). There is broad agreement about the trends, though the levels vary widely, depending on the datasets used and the techniques employed to deal with some data and measurement issues.

Using Sequential Regression Multiple Imputation (SRMI) to impute values for reported zero or missing incomes, Yu (2009) found a strong increase (seven or eight points) in the Gini coefficient between 1996 and 2001 (Table 3). Supporting evidence comes from other studies 
employing alternative measures: Leibbrandt el al (2006) found an increase in the Gini from 0.68 to 0.73 using one method, and from 0.74 to 0.79 using another; Simkins (2004) found that the Gini coefficient for households grew from 0.66 to 0.69 ; and Ardington et al (2005) concluded that the Gini coefficient rose from 0.74 to 0.82 . There is thus agreement about the trends, though the levels vary widely.

Table 3: Gini coefficients, Census / CS vs. IESs

\begin{tabular}{|l|c|c|c|}
\hline Census / Survey & $\begin{array}{c}\text { Post-SRMI-1 per } \\
\text { capita income }\end{array}$ & $\begin{array}{c}\text { Post-SRMI-2 per } \\
\text { capita income }\end{array}$ & $\begin{array}{c}\text { Per capita income } \\
\text { (using COICOP }\end{array}$ \\
\hline IES 1995 &.. &.. & 0.660 \\
\hline Census 1996 & 0.734 & 0.694 &.. \\
\hline IES 2000 &.. &.. & 0.709 \\
\hline Census 2001 & 0.817 & 0.756 &.. \\
\hline IES 2005/2006 &.. &.. & 0.715 \\
\hline Community Survey 2007 & 0.759 & 0.743 &.. \\
\hline
\end{tabular}

Note: IES2005 was classified according to the new structure of national accounts of the United Nations. For comparisons over time, re-classification of some items from the old Standard Trade Classification to the new COICOP was necessary

Source: Yu 2009, 44, Table 22

Inequality at the aggregate level also showed a less clear trend after the turn of the century (Van der Berg, Louw \& Yu 2008; Van der Berg, Louw \& Du Toit 2009; Leibbrandt et al. 2010). Between Census 2001 and the Community Survey of 2007, there was either a strong decline in the Gini (according to Yu (2009)'s SRMI1) or more likely, using his more appropriate SRMI2, a minor (1 point) decline in the Gini coefficient. The IES implies that a further half a point rise took place between 2000 and 2005. Yu's careful analysis of the three IES surveys in which he strove to obtain comparability in definitions led him to conclude that "...there was an evident increase of Gini coefficient between IES1995 and IES2000, while the IES2000 and IES2005 Gini coefficient values were very similar, regardless of the income categorization method used." (Yu 2008: 20).

Thus there was probably a strong upward trend in inequality as measured by the Gini coefficient in the second half of the 1990s, and largely stable inequality since. Inequality is clearly very high, but how high is not clear. Various measurement errors may lead to both high incomes and low incomes being under-estimated, thus the net effect of mismeasurement on inequality is not clear. Based on available datasets and using comparatively similar methods, Yu (2008) shows Gini coefficient ranging between 0.612 and 0.826 in this period, but with little trend: Ginis simply differ greatly even for the same year, due to data comparability and measurement issues.

There is less agreement about poverty trends in the period 1995-2000, with anything from a strong rise (Leibbrandt, Levisohn and McCrary 2010) to a moderate decline (UNDP 2003; Van der Berg \& Louw 2004; Van der Berg, Louw \& Yu 2008; Leibbrandt et al. 2010) being found. The strongest support seems to be for a view that the poverty headcount rose moderately in this period (Yu 2008, 2010; Agüero, Carter \& May 2005 for Kwazulu-Natal.) 
Looking at the period after 2000, Van der Berg, Louw \& Yu (2006) used less conventional data sources (the regular All Media and Products Survey, AMPS) in an attempt at early identification of poverty trends for policy purposes. The results of this analysis indicated that poverty declined after 2000, driven largely by the expansion of social grants, although increased employment and the economic growth which made both employment growth and grant expansion possible also contributed. This view has now become the conventional wisdom: Meth (2006) analysed data from Labour Force Surveys and also found poverty to have fallen after 2000, although not to the same extent. Agüero, Carter and May (2005) reported that between 1998 and 2004 poverty declined among black and Indian households in KwaZulu-Natal, although Leibbrandt et al. (2010) find no strong downward trend at the national level comparing NIDS (2008) data to IES2000. Supporting evidence comes from the GHS surveys on the prevalence of hunger: Households reporting that a child went hungry halved between 2002 and 2007, from just over 31 per cent to 15 per cent, before a slight reversal in 2008 during the recession (Figure 2; see also Seekings 2006).

Despite reservations about this data source for income distribution analysis, the poverty trends identified by Yu $(2010,26)$ and shown in Table 4 capture the consensus view for the full posttransition period, that poverty first increased before it declined (though there is disagreement on the magnitude of the trends. The initial rise in poverty is probably due to a combination of sluggish economic growth and poor labour market prospects in the second half of the 1990s, while the recent decline in poverty resulted from faster economic growth, an improved labour market and especially increased social grant spending (Van der Berg, Louw \& Du Toit 2009, 21)

Figure 2: Households reporting that children went hungry in the past year

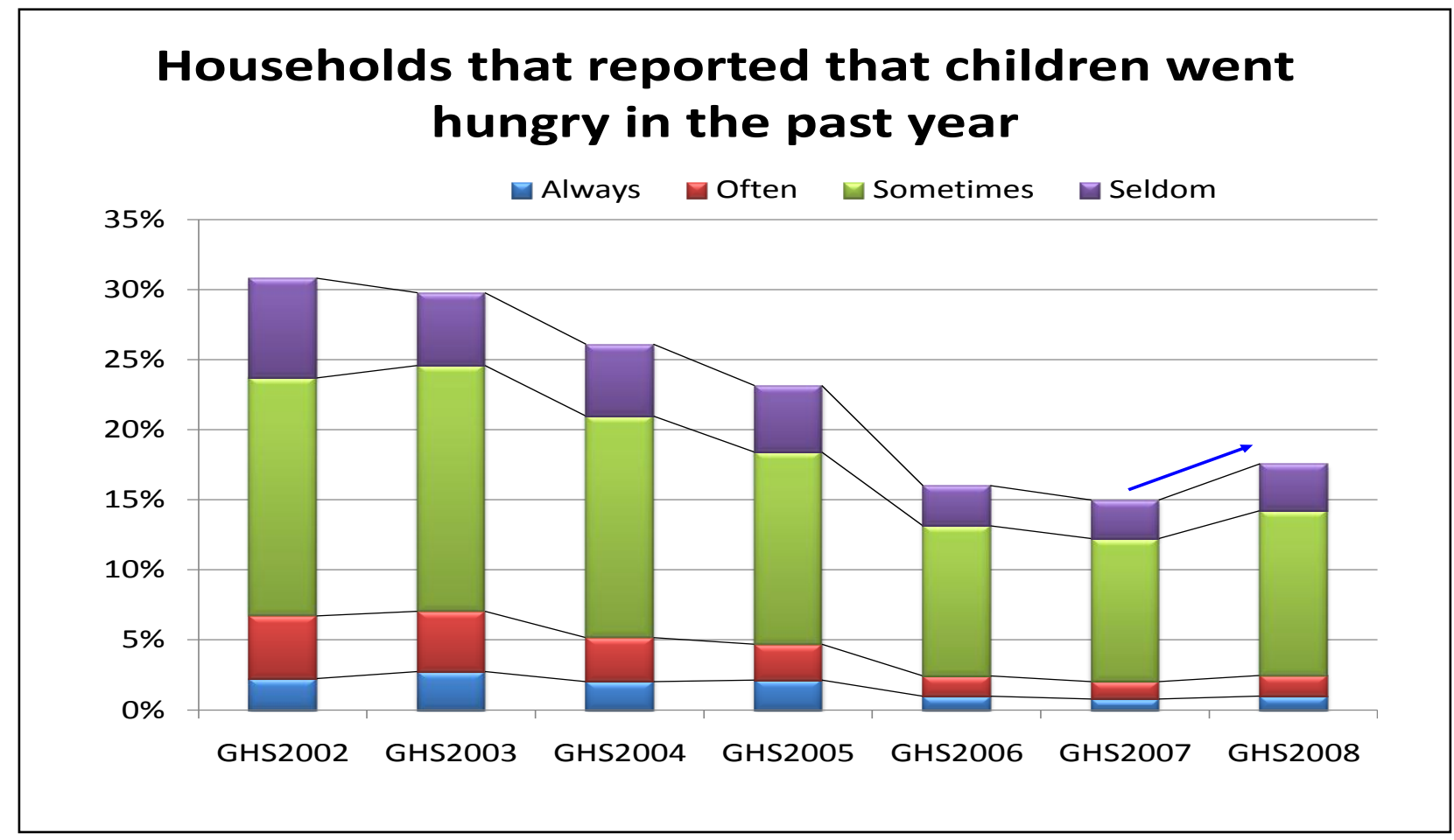

Source: Calculations from General Household Surveys (GHS) 
Table 4: Poverty at a poverty line of $\mathbf{R 2 5 3 2}$ per capita per years in 2000 Rand terms based on two censuses and the Community Survey

\begin{tabular}{|l|c|c|c|}
\hline & $\begin{array}{c}\text { Census } \\
\mathbf{1 9 9 6}\end{array}$ & $\begin{array}{c}\text { Census } \\
\mathbf{2 0 0 1}\end{array}$ & $\begin{array}{c}\text { Community Survey } \\
\mathbf{2 0 0 7}\end{array}$ \\
\hline Black & $54.1 \%$ & $53.8 \%$ & $39.6 \%$ \\
\hline Coloured & $20.5 \%$ & $21.0 \%$ & $15.5 \%$ \\
\hline Indian & $5.4 \%$ & $5.5 \%$ & $5.8 \%$ \\
\hline White & $1.8 \%$ & $1.1 \%$ & $0.9 \%$ \\
\hline Total & $44.1 \%$ & $44.6 \%$ & $32.9 \%$ \\
\hline
\end{tabular}

Source: Yu 2009: 39

\section{Inequality within groups versus inequality between groups}

Estimates from varied data sources are in broad agreement that intra-group inequality has been rising within all race groups. It is particularly high amongst the black population, but also quite high even for the least unequal group, the white population. New opportunities for parts of the black population, previously constrained by apartheid-era policies, stimulated black upward mobility, while the removal of the protection earlier offered to the white population may have caused some downward mobility in parts of this group (Moll 2000). The Gini coefficient is rising for all groups separately, but not necessarily for South Africa as a whole, because the major component of overall income inequality - inequality between race groups - has been declining.

The Theil index, which allows for a decomposition of inequality into a within-group and a between-group component, shows that while within-group inequality has risen, the betweengroup inequality component has declined. In other words, inequality is gradually becoming less based on race, as it declines between groups but grows within groups. Whereas $61 \%$ of inequality in the AMPS data could in 1993 still be ascribed to inequality between groups, that proportion has now dwindled to $35 \%$. Results from other datasets confirm this pattern.

Overall conclusions from the literature on trends in poverty and income distribution can be summarised as in Table 5 and have been well encapsulated by Leibbrandt et al. (2010, 18-19):

"...there is something of a consensus around the direction of post-Apartheid inequality and poverty trends even if there are disagreements about the precise levels at any point in time. Aggregate inequality has remained stubbornly high and perhaps even increased. This is being driven by increasing intra-race inequality. In the adjustments to South African society accompanying the advent of democracy, such dynamism is not unexpected and not necessarily bad. However, the fact that the post-Apartheid society started off with such a high level of inequality certainly adds an ominous note to this trend. Given the skewed distribution of human and physical assets that undergirds these trends, it is unsurprising that there has not been a dramatic improvement in money-metric poverty over the early years of the post-Apartheid period. More recent years have witnessed stronger gains against poverty. Indeed, one of the useful features of the interchange between Meth and Van der Berg et al. is that it has highlighted the importance of the social grant system as a social safety net in South Africa. The importance of the state old 
age pension has been recognized from the outset of the post-Apartheid period and the demonstrable impact of the child support grant in the last six years is notable. This takes the aggregate empirical picture a little closer to the real application of post-Apartheid policy in South Africa."

Table 5: Post-transition trends in poverty and income distribution

\begin{tabular}{|l|c|c|}
\hline & \multicolumn{2}{|c|}{ Approximate time period } \\
\hline & $\mathbf{1 9 9 4 - 2 0 0 0}$ & $\mathbf{2 0 0 0 - 2 0 0 6}$ \\
\hline Aggregate inequality & Rising strongly & Little change \\
\hline Inequality between groups & Declining & Declining \\
\hline Inequality within groups & Rising strongly & Rising \\
\hline Poverty headcount & Rising moderately & Declining strongly \\
\hline
\end{tabular}

\section{The centrality of the labour market}

By far the largest share of overall current income derives from labour remuneration, though its share has declined from a peak of $81 \%$ in 1976 to 63\% in 2005, according to South African Reserve Bank data. The share of transfer incomes (social grants) is small at almost 7\% (though it has been rising, from just 3\% in 1960) and the residual share has grown a lot since the mid 1980 s, from around $20 \%$ to $31 \%$ in 2005 . As residual (largely property) incomes are quite unequally distributed, their rising share may put upward pressure on inequality.

Although the Gini-coefficient is not decomposable between groups where incomes overlap, it is possible to decompose it by income source. Such a decomposition often distinguishes what Leibbrandt, Bhorat \& Woolard (2001: 23) referred to as "...the key labour market, asset ownership and state welfare processes driving South Africa's inequality", viz. wages, other income (including dividends), and transfers from government. Virtually two-thirds of households earn wage income, but amongst these households the Gini coefficient for wage income in IES2005/6 was a very high 0.651 . This reflects the great inequality in wage earnings between households, because of differences in both wage levels and the number of wage earners. Using IES data, differentials in wage earnings per household statistically "explain" $77.9 \%$ of overall inequality. ${ }^{9}$

Residual income contributes to overall inequality, as one would expect - if this was the only source of income, the Gini would have been 0.878. In contrast, government transfers (mainly social grants) benefit especially lower income earners. They are only weakly related to overall incomes. Social grants reduce poverty - but have virtually no impact on inequality. Armstrong and Burger $(2009,17)$ find that, despite a large impact on poverty, social grants reduced the Generalised Entropy measure 2 (half the square of the coefficient of variation) by only $1 \%$. As the considerable literature on measuring the impact of social grants (Case \& Deaton 1998; Case,

\footnotetext{
${ }^{9}$ Classifying income sources slightly differently, Leibbrandt, Woolard, Finn \& Argent (2010: 34-5) find this percentage to be $88 \%$ in the 1993 PSLSD, $91 \%$ in IES2005/6 and $85 \%$ using the 2008 NIDS data.
} 
Lin \& McLanahan 1999; Bertrand, Miller \& Mullainathan 2000; Duflo 2000; Edmonds, Mammen \& Miller 2001; Keller 2004; Posel, Fairburn \& Lund 2006; Klasen \& Woolard 2009) has by now well-established, grants have an important economic influence, including possibly affecting household formation and composition and migration decisions.

Decomposition analysis shows that most income inequality originates in the labour market, through the distribution of jobs and the wage formation processes. Thus change in South African inequality must start with a reduction of inequality in wage earnings. If grants have little impact, and even assuming that property income does not skew distribution, The high inequality of wage earnings effectively sets a floor to aggregate income inequality, while property income further increases inequality and social transfers only mildly ameliorate it. Without more equal labour market outcomes, aggregate inequality will remain high and will undoubtedly encourage further direct labour market interventions in an attempt to affect distributional outcomes.

Some see more jobs as an answer to this, to give the poor access to income and reduce wage earning inequality between households. But that is too simple a solution. A simulation exercise using IES2000 data showed that jobs would have a more beneficial effect on poverty than on inequality: $2 \frac{1}{2}$ million additional jobs would reduce the Gini coefficient by only about 0.033 , but would reduce the poverty headcount ratio by almost 9 percentage points. In contrast, an average wage increase of as much as 30\% would only reduce the poverty headcount by about 4 percentage points, while leaving the Gini coefficient slightly higher (0.011 points).

Thus the pattern of wage inequality itself needs to change to really affect aggregate income distribution in a major way. The manifestation of wage inequality is a sharply convex returns to labour function. This shows evidence of much higher productivity and wages being associated with higher levels of educational attainment. This reflects much stronger demand for educated than for less educated labour, and perhaps also encapsulates employer preferences for higher quality labour. Earnings functions indicate that the unexplained part of earnings differentials between race groups remains stubbornly high (Burger \& Jafta 2006). This unexplained residual is often considered an upper estimate for labour market discrimination, but in South Africa it may to a considerable degree result from differences in the quality of education received by members of different race groups. Thus educational quality is a central concern in labour market outcomes.

The convex returns to education is evidence of higher productivity being associated with higher attainment (Keswell \& Poswell 2004; Bhorat \& Leibbrandt 2001). The steeply rising slope of Mincerain earnings function for South Africa after matric points to a threshold effect - below a certain level and quality of education, an additional year of education is not greatly valued in the labour market, both in terms of employment probability and in wage earnings.

\section{Policy and distribution}

The complexity of the economic interactions makes it almost impossible to know the distributional outcome of policies. Norman Bromberger $(1982,167)$ warned that "We must avoid assuming that if there is a change, or no change, government policy is responsible. Nor should 
we assume that government policies are either coherent or necessarily successful". Nevertheless, it is clear that current racial inequalities still reflect the large shadow of South Africa's racial history. Two policy issues deserve special mention: government social spending, and education.

\section{Social spending}

Social spending inequalities were substantially reduced from the mid-1970's onwards (Van der Berg 2001, 2006, 2009b). After the political transition, government social spending per person increased in real terms by $21 \%$ from 1995 to 2000 and by a further $40 \%$ growth in the first six years of this century, and spending also became much better targeted. Social spending is indeed now extremely well targeted to the poor for a middle income country. Targeting occurred through the means test for social grants, through the fact that poorer people have more children who benefit from public school spending, and because the rich largely avoid using public health facilities, leaving a larger share of the benefits (though a poor quality of service) to those who cannot afford to vote with their feet to avoid the public health sector. The relative shift in resources towards the best targeted social spending programme, social grants, further improved targeting.

Due to these fiscal shifts there was a large increase in spending on the poorest quintiles, with the economically more disadvantaged being the major beneficiaries. While spending per capita on whites was almost nine times that on blacks in the mid 1970's (R4 795 versus R564, in 2000 Rand terms), spending per capita on blacks is now almost twice as much as on whites (R3 013 versus R1 568). (Van der Berg 2009)

Such massive fiscal redistribution cannot compensate for highly unequal income distribution in the market. Moreover, there are fiscal limits to redistribution of this nature and capacity constraints in the state apparatus that limit the felt benefits from such redistribution, as the quality of government services is often poor. This is well illustrated in the field of education.

\section{Education}

Despite apartheid-era policies, a dramatic expansion of education took place long before the political transition. This led to a remarkable narrowing of the gap in years of education attained (Figure 3). (Van der Berg 2007, 2009a). In an international context, the progress of successive black cohorts in attaining more years of education completed was spectacular, as the comparison in the Figure with data for three other developing countries shows. Lam (1999) also illustrated this in a comparison of educational attainment in South Africa and Brazil.

But education levels below matric contribute relatively little to improving labour market outcomes. Some two-thirds of the white matric-aged cohort complete matric, versus just over one-quarter of the black cohort. Especially amongst the young, many not completing high school are effectively excluded from the economic mainstream, given the way the labour market interprets educational attainment. If educational quality is considered, differences are even larger, as access to quality education remains highly skewed. While black children in 2007 were $83 \%$ of the matric-aged cohort and already constituted $78 \%$ of matric passes in public schools, 
they accounted for only $59 \%$ of the endorsements ("university exemptions"), for $34 \%$ of those who passed Mathematics at the Higher Grade with an A, B or C aggregate (i.e. those who can potentially continue onto university further studies in engineering, medicine, science or even commerce), and for only $14 \%$ of those who passed matric with an A aggregate. ${ }^{10}$

Figure 3: Educational attainment (years of education completed) by birth cohort and race, with comparisons to some other middle-income developing countries

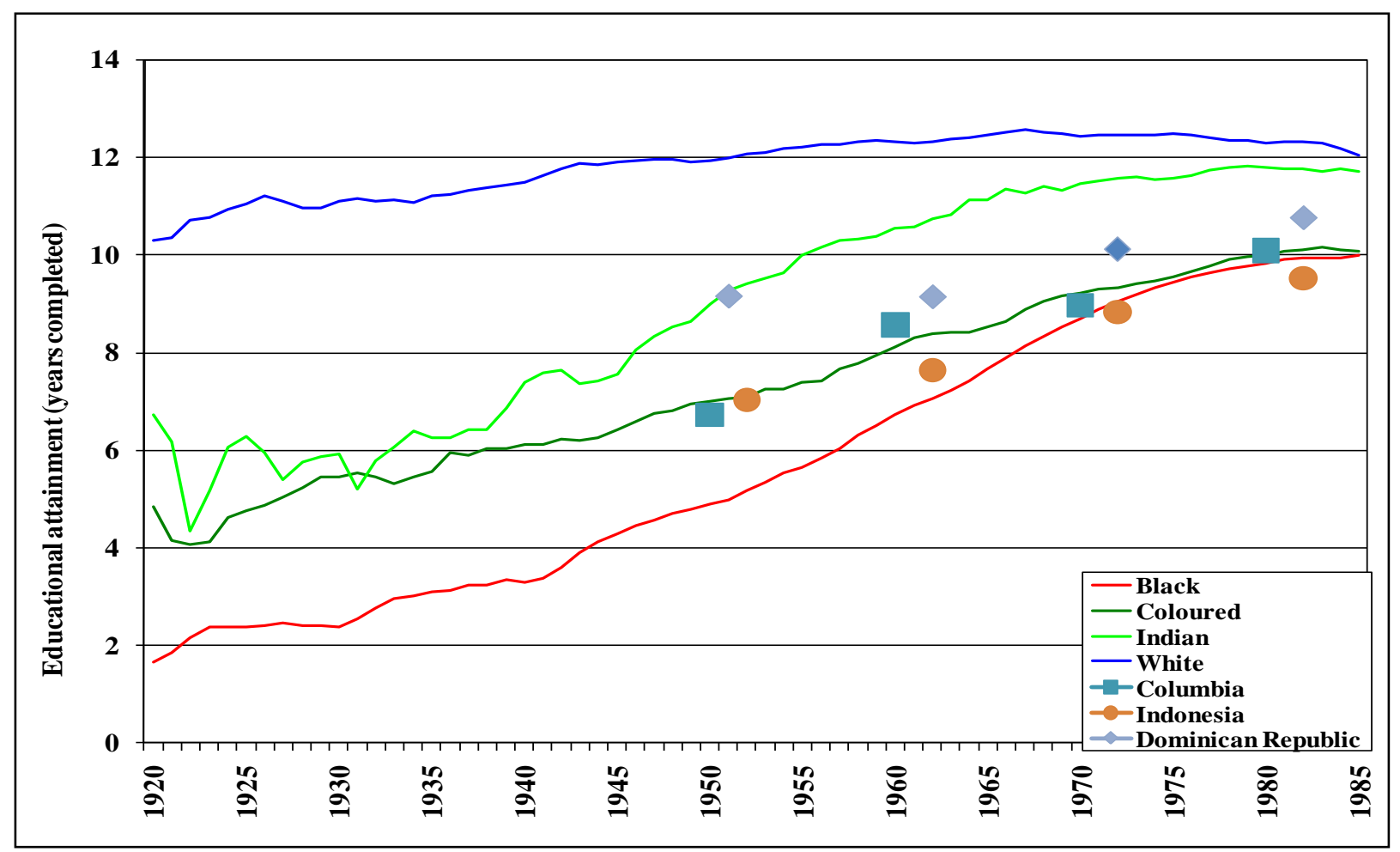

Source: Own calculations from Community Survey 2007 and World Bank’s Edustats.

\section{Conclusion and discussion}

This paper has discussed the quantitative dimensions of poverty and income distribution in South Africa. Severe data quality and measurement issues make strong statements on trends income inequality difficult to substantiate. Nevertheless, a few conclusions can be drawn:

- The relationship between poverty and inequality is not straightforward; poverty can indeed decline while inequality grows, but rising inequality can also dominate any beneficial impacts of economic growth on poverty. Poverty alleviation must be higher on the policy agenda than reducing inequality, though South African history makes attention to inter-racial equity an important concern in its own right.

\footnotetext{
${ }^{10}$ Substantially more members of the small Indian population than blacks passed Matric with an A aggregate.
} 
- Sustained economic growth since the political transition allowed more attention to be paid to poverty alleviation, with some success: Social grants were successful in the period after 2000 in considerably reducing money-metric poverty.

- However, overall inequality has not improved and remains extremely high. But its nature has changed: Inter-racial (between-group) income distribution improved considerably, but income distribution within groups worsened. Thus the racial dimension of inequality has been softened.

- Growing inequality within the black population is also associated with rapid growth of the black middle class, a rise too rapid and large to be ascribed to BEE policies alone.

- However, comparability issues between data sources and the difficulty of capturing some sources of income well (such as dividends) cast some doubt on these conclusions, as do the large and inexplicable differences in levels of Gini coefficients as determined using different data sources, even for the same period.

- Decomposition of inequality by income source shows that wage income is the dominant component in overall income inequality. To a large extent wage inequality derives from differences in both educational levels and educational quality.

Fiscal redistribution through the grant system has had some success in reducing poverty. However, fiscal and state capacity sets limits to such redistribution and makes this an inauspicious tool for future change. The fiscal capacity constraint arises from the fact that grant spending already constitutes a high proportion of GDP and that such grants need to compete with other public spending. The state capacity constraint relates to the fact that social delivery has been greatly constrained by the limited ability of the public sector to convert spending into improved outcomes for the poor. Transfers also cannot really affect inequality much. Their overall magnitude is too small, even in South Africa, to have a great effect on inequality measures, despite good targeting.

Job creation, though crucial for poverty reduction, will also do little to reduce overall inequality. The weak endowments of those currently unemployed would not assure them of high labour market earning. Thus even if they were employed, it would probably be at low wages, thus leaving wage and hence aggregate inequality high and little affected. In the absence of improved education, direct interventions to artificially change labour market outcomes also hold little prospect of improving poverty and distribution and may reduce the efficient functioning of the labour market, with various possible side-effects.

Thus the labour market is at the heart of inequality, and central to labour market inequality is the quality of education. To reduce income inequality substantially requires a different wage pattern based on better human capital for the bulk of the population. Prospects for this at present appear inauspicious. 


\section{BIBLIOGRAPHY:}

Agüero, J., M.R. Carter \& J. May. 2005. Poverty and inequality from the first decade of democracy: Evidence from KwaZulu-Natal. Paper for Oxford Centre for Study of African Economies/Stellenbosch University Department of Economics conference on "South African Economic Policy under Democracy: A Ten Year Review", Stellenbosch, 28-29 October.

Ardington, C. D. Lam, M. Leibbrandt \& M. Welch. 2005. The sensitivity of estimates of postapartheid changes in South African poverty and inequality to key data imputations. CSSR Working Paper No. 106. Cape Town: Southern Africa Labour and Development Research Unit, Centre for Social Science Research.

Armstrong, P. \& C. Burger. 2009. Poverty, Inequality and the Role of Social Grants: An Analysis using Decomposition Techniques. Working Papers 15/2009, Stellenbosch University, Department of Economics.

Bertrand, M., D. Miller, \& S. Mullainathan. 2000. Public Policy and Extended Families: Evidence from South Africa. NBER Working Paper 7594. Cambridge, USA. National Bureau for Economic Research. March. 46pp.

Bhorat, Haroon \& Murray Leibbrandt. 2001. Modelling vulnerability and low earnings in the South African labour market. Ch. 4 in: Bhorat, Haroon; Leibbrandt, Murray; Maziya, Muzi; Van der Berg, Servaas; \& Woolard, Ingrid. 2001. Fighting poverty: Labour markets and inequality in South Africa. Cape Town: UCT Press

Bhorat, Haroon; Murray Leibbrandt; Muzi Maziya; Servaas van der Berg; \& Ingrid Woolard,. 2001. Fighting poverty: Labour markets and inequality in South Africa. UCT Press: Cape Town

Bourguignon, Francois \& Christian Morrisson. 2002. Inequality among world citizens: 18201992. American Economic Review 92(4): 727-44.

Bromberger, Norman. 1982. Government policies affecting the distribution of income, 19401980. In: Schrire, Robert (ed.). 1982. South Africa: Public policy perspectives. Cape Town: Juta:. 165-203

Burger, Rulof \& Rachel Jafta. 2006. Returns to race: Labour market discrimination in PostApartheid South Africa. Working Paper 04/2006, Stellenbosch University: Department of Economics

Case, Anne \& Angus Deaton. 1998. Large cash transfers to the elderly in South Africa. Economic Journal 108(450): 1330-61

Deaton, Angus. 1997. The analysis of household surveys: A microeconometric approach to development policy. Johns Hopkins University Press, Baltimore

Duflo, Esther. 2000. Grandmothers and granddaughters: Old age pensions and intra-household allocation in South Africa. NBER Working Paper 8061. Cambridge, USA. National Bureau for Economic Research. December. 36pp.

Edmonds, E., K. Mammen \& D. Miller, D. 2001. Household composition responses to large pension receipts in South Africa. Mimeo, Princeton University.

Hoogeveen, J.G. \& B. Özler. 2006. Poverty and inequality in post-apartheid South Africa: 1995 to 2000. In: H. Bhorat \& R. Kanbur (eds), Poverty and policy in post-apartheid South Africa. Human Sciences Research Council: Cape Town: 59 - 94.

Kane-Berman, John. 1991. The silent revolution. Second edition. Johannesburg: SA Institute of Race of Relations. 
Keller, Sonja. 2004. Household formation, poverty and unemployment - the case of rural households in South Africa. South African Journal of Economics 72(3): pp.437-483

Keswell, Malcolm \& Laura Poswell, 2004. Returns to education in South Africa: A retrospective sensitivity analysis of the available evidence. South African Journal of Economics 72(4): pp.834-860

Klasen, Stefan and Ingrid Woolard. 2009. Surviving unemployment without state support: unemployment and household formation in South Africa. Journal of African Economies 18(1): pp.1-51

Lam, David. 1999. Generating extreme inequality: Schooling, earnings, and intergenerational transmission of human capital in South Africa and Brazil. Research Report No. 99-439. Population Studies Center, University of Michigan.

Leibbrandt, Murray, Haroon Bhorat and Ingrid Woolard. 2001. Understanding contemporary household inequality in South Africa. Chapter 2 in: Bhorat, H.; Leibbrandt, M.; Maziya, M.; Van der Berg, S.; \& Woolard, I. 2001. Fighting poverty: Labour markets and inequality in South Africa. UCT Press: Cape Town

Leibbrandt, M., J. Levinsohn, \& J. McCrary. 2010. Incomes in South Africa after the fall of apartheid. Journal of Globalization and Development 1(1).

Leibbrandt, M., L. Poswell, P. Naidoo, M. Welch \& I. Woolard. 2006. Measuring recent changes in South African inequality and poverty using 1996 and 2001 Census data. In: H. Bhorat \& R. Kanbur (Eds). Poverty and policy in post-apartheid South Africa. Human Sciences Research Council: Cape Town: 95 - 142.

Leibbrandt, Murray, I. Woolard, A. Finn \& J.Argent. 2010. Trends in South African income distribution and poverty since the fall of Apartheid. OECD Social, Employment and Migration Working Papers No. 101. Paris: OECD

Leibbrandt, Murray, Chris Woolard \& Ingrid Woolard. 1996. The contribution of income components to income inequality in South Africa: a decomposable Gini analysis. Living Standards Measurement Survey (LSMS) Working Paper 125. Washington DC: World Bank.

Leibbrandt, M., I. Woolard \& C. Woolard. 2009. Poverty and inequality dynamics in South Africa: Post-apartheid developments in the light of the long-run legacy. 2009. Chapter 10 in: Aron, J., Kahn, B. \& Kingdon, G. (Eds.) South African Economic Policy under Democracy. Oxford: Oxford University Press.

Maddison, Angus. 2007. The World Economy. Volume II: Historical Statistics 8-8: The World Economy 1-2001 AD. Paris: OECD Development Centre.

McGrath, Michael D. 1983. The distribution of personal income in South Africa in selected years over the period from 1945 to 1980. Ph.D. thesis. Durban: University of Natal.

McGrath, Michael D. 1990a. Economic growth, income distribution and economic change. In: Nattrass, Nicoli \& Ardington, Elizabeth (eds.), 1990. The political economy of South Africa. Oxford: Oxford University Press.

McGrath, Michael D. 1990b. Income redistribution: the economic challenge of the 1990s. In Schrire, R (ed.). Critical choices for South Africa: An agenda for the 1990s. Cape Town: Oxford University Press

Meth, Charles. 2006. Income poverty in 2004: A second engagement with the recent Van der Berg et al figures. Working Paper 47. Durban: School of Development Studies, University of KwaZulu-Natal. 
Moll, P. 2000. Discrimination is declining in South Africa but inequality is not. Studies in Economics \& Econometrics 24(3): 91-109.

Posel, D., J.A. Fairburn \& F. Lund. 2006. Labour migration and households: A reconsideration of the effects of the social pension on labour supply in South Africa. Economic Modelling 23(5): 836-853

Quah, Danny. 2002. One third of the world's growth and inequality. Wider Discussion Paper 2002/38. Helsinki: World Institute for Development Economics Research.

Sala-i-Martin, Xavier. 2002a. The world distribution of income (estimated from individual country distributions). NBER Working Paper No. 8933. Cambridge, Mass.: National Bureau for Economic Research.

Sala-i-Martin, Xavier. 2002b. The disturbing 'rise' of world income inequality. NBER Working Paper 8904. Cambridge, Mass.: National Bureau for Economic Research.

Seekings, J. 2006. Facts, myths and controversies: The measurement and analysis of poverty and inequality after apartheid. Paper presented to the DPRU/TIPS conference. Johannesburg, 18-20 October.

Simkins, Charles. 1991. The Urban Foundation income distribution model: Phase One. Mimeo. Johannesburg: Urban Foundation.

Simkins, Charles. 2000. Income Inequality and Unemployment in South Africa: Facts, Causes and Perspectives. In: Bridging the Gap between Rich and Poor. Proceedings of Konrad Adenauer Stiftung Conference, Bronkhorstspruit. May: 13-26.

Simkins, Charles. 2004. What happened to the distribution of income in South Africa between 1995 and 2001? Unpublished draft. [Online.] Available: www.sarpn.org

Spandau, A.M.K.M. 1971. Income distribution and economic growth in South Africa. Doctoral thesis. Pretoria: University of South Africa.

Statistics South Africa. 2002. Earning and spending in South Africa: Selected findings and comparisons from the income and expenditure surveys of October 1995 and October 2000. Pretoria: Government Printer.

UNDP. 2003. South Africa Human Development Report 2003: The Challenge of Sustainable Development. UNDP South Africa: Oxford University Press.

Van der Berg, Servaas. 1989a. On inter-racial income distribution in South Africa. South African Journal of Economics 57(1)

Van der Berg, Servaas. 1989b. Long term economic trends and development prospects in South Africa. African Affairs 88(351): 187-203

Van der Berg, Servaas. 2001. Trends in racial fiscal incidence in South Africa. South African Journal of Economics 69(2), June 2001: 243-268

Van der Berg, Servaas.2006. Public spending and the poor since the transition to democracy. Ch.5 in: Haroon Bhorat \& Ravi Kanbur (eds.). 2006. Poverty and policy in postapartheid South Africa. HSRC Press: Pretoria: 201-231.

Van der Berg, Servaas. 2007. Apartheid's enduring legacy: Inequalities in education. Journal for African Economies 16(5), November 2007: 849-880

Van der Berg, Servaas. 2009a. The persistence of inequalities in education. Chapter 12 in: Janine Aron, Brian Kahn \& Geeta Kingdon (eds). South African Economic Policy under Democracy. Oxford University Press: Oxford: 327-354.

Van der Berg, Servaas. 2009b. Fiscal incidence of social spending in South Africa, 2006. Working Papers 10/2009. Stellenbosch University, Department of Economics. 
Van der Berg, Servaas \& Megan Louw. 2004: Towards time series estimates of distribution and poverty. South African Journal of Economics 72(3): 546 - 572.

Van der Berg, Servaas; Megan Louw \& Leon du Toit. 2009. Poverty trends since the transition: What we know. Working Papers 19/2009. Stellenbosch University, Department of Economics.

Van der Berg, Servaas, Megan Louw \& Derek Yu. 2008. Post-transition poverty trends based on an alternative data source. South African Journal of Economics 76: 58-76

Whiteford, A. \& D.E. van Seventer. 2000. South Africa's changing income distribution in the 1990s. Studies in Economics \& Econometrics 24(3): 7-30

World Bank. 1997. World Development Report 1997. World Bank: Washington, D.C.

$\mathrm{Yu}$, Derek. 2007. The comparability of the Statistics South Africa October Household Surveys and Labour Force Surveys. Working Papers 17/2007. Stellenbosch University, Department of Economics.

Yu, Derek. 2008. The comparability of Income and Expenditure Surveys 1995, 2000 and 2005/2006. Working Papers 11/2008. Stellenbosch University, Department of Economics.

Yu, Derek. 2009. The comparability of Census 1996, Census 2001 and Community Survey 2007. Working Papers 21/2009. Stellenbosch University, Department of Economics.

$\mathrm{Yu}$, Derek. 2010. Poverty and inequality trends in South Africa using different survey data. Working Papers 04/2010. Stellenbosch University, Department of Economics. 